\title{
Incidence of Respiratory Problems in the Population of Santana do Ipanema, Brazil, with the Burning of Biomass
}

\author{
José Crisólogo De Sales Silva ${ }^{1 *}$, Fabio Soares Campos ${ }^{2}$ and Nathan Cristhiano Ferreira De Araujo ${ }^{2}$ \\ ${ }^{1}$ State University of Alagoas, Brazil \\ ${ }^{2}$ Biologist by the State University of Alagoas, Brazil
}

Submission: May 01, 2017; Published: June 05, 2017

"Corresponding author: José Crisólogo De Sales Silva, State University of Alagoas, Uneal, Brazil, Email: jose.crisologo@uneal.edu.br

\begin{abstract}
The tradition of wood burning in bonfires in the June festivities increases the number of cases of patients with respiratory diseases in the public health units of Santana do Ipanema, Alagoas, Brazil. The greater number of cases is concentrated in the urban zone and in the period after the festivities. Besides being a public health problem, burning is also an environmental problem, since the wood used is extracted from the native forests of the Caatinga Biome and Forest Atlantic Biome. The objective of this study was to verify the number of registered cases of patients with respiratory disease problems in the Public Health units of Santana do Ipanema, in the months before and after the June festivities. The sociocultural-religious phenomenon of lighting fires, on the occasion of the June celebrations, intensifies the problems of public health, besides the environmental problem coming from this tradition.
\end{abstract}

Keywords: Bonfires; Public health; Respiratory diseases; Smoke

\section{Introduction}

Chronic respiratory diseases (CKD) are chronic diseases of both the upper and lower airways. Asthma, allergic rhinitis and chronic obstructive pulmonary disease (COPD) are the most common CKD. They represent one of the biggest health problems worldwide. Hundreds of millions of people of all ages suffer from these diseases and respiratory allergies in every country in the world and more than 500 million of them live in developing countries. CKDs are increasing in prevalence particularly among children and the elderly. They affect the quality of life and can cause disability in affected individuals, causing great economic and social impact. The physical, emotional and intellectual limitations that arise with the disease, with consequences in the life of the patient and his family, generate human suffering.

The World Health Organization (WHO) and the World Bank estimate that four million people with CKD may have died prematurely in 2005 and projections are likely to increase the number of deaths in the future. As a strategy to address this global health problem, WHO has created the Global Alliance against Chronic Respiratory Diseases (GARD) [1].

These numbers show that a chronic respiratory disease affects 2 out of 10 Brazilians. The rates of respiratory diseases increase about 40\% among Alagoas. Sinusitis, Allergic Rhinitis, Pharyngitis, Pneumonia and Respiratory Failure are further aggravated in winter by changes in temperature, dry air and high concentration of toxic substances, significantly increasing the flow of people in doctors' offices and hospitals. Because it is a widespread event, mainly in the Northeast region of Brazil, the June celebrations assume a cultural and religious meaning, with the participation of all population, the streets are full of fires, dance huts.

The burning of wood of June fires has become an environmental problem, the use of trees in the native forests to maintain this folkloric/religious tradition, ends up contributing to accelerate the process of desertification and degradation of riparian forests and the Caatinga biome. The contras contrasted in the calendar of June, on the seventeenth day is celebrated the World Day to Combat Desertification and Drought, after a week, on the twenty-fourth is honored St. John, with the burning of thousands of $\mathrm{m} 3$ of Wood in fires of various sizes [2].

Regarding deforestation in the Caatinga biome area, according to a document published by the Ministry of the Environment (MMA, 2010), the main cause for this action is 
the withdrawal of native forest converted to firewood and charcoal "to feed domestic stoves, The furnaces of the bakeries, potteries, industrial boilers and the erroneous practices of agriculture such as coivara (burning of plant branches on fire), which corresponds to the burning of native vegetation for the implantation of agriculture or pasture " [2]. The objective of this study was to verify the number of registered cases of patients with respiratory disease problems in the Public Health units of Santana do Ipanema, State of Alagoas, Brazil, in the months before and after the festivities of June.

\section{Methodology}

For the development of this article, questionnaires of direct and open questions for interviews with health unit managers were used to answer questions about how to catalog, store, request and use the cadastral and informational data about the users of the public health service, Considered as patients. In addition, the health units of the municipality provided cadastral data in their own forms generated in the data storage system of the Municipal Health Department of Santana do Ipanema and through online consultations to the Scielo system via the worldwide computer network, Internet. This work was elaborated and developed in the city of Santana do Ipanema, which is located in the middle of semiarid zone, in the state of Alagoas, approximately $207 \mathrm{~km}$ from the Alagoas state capital, Maceió, with an approximate altitude of $250 \mathrm{~m}$ and geographic coordinates of 922'40 "Of Latitude South, and 37ำ14'42" of Longitude Este (IBGE, 2000) with an area of $437,847 \mathrm{~km} 2$. The city at the time of the work carried out had approximately 44,949 thousand inhabitants, distributed in urban and rural areas (Map 1).

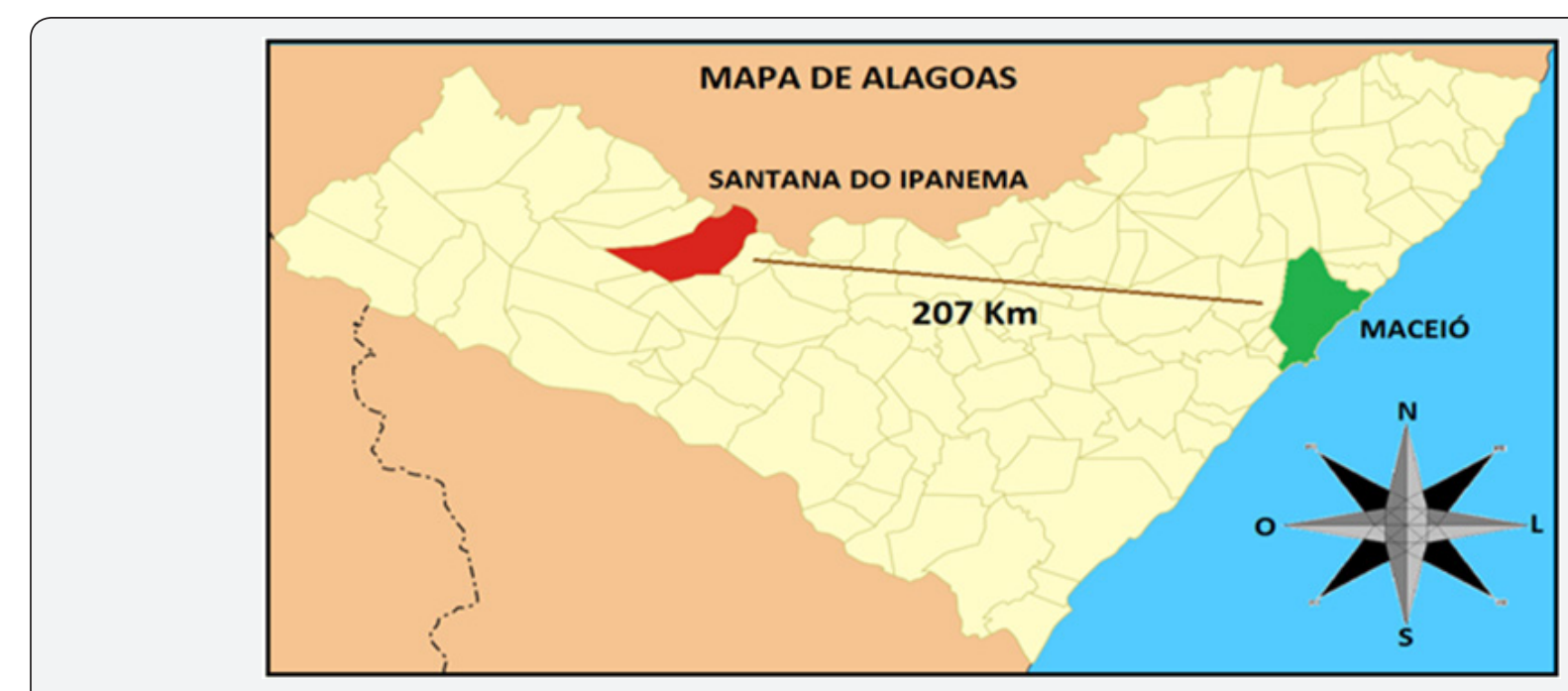

Map 1: Geographical map of Alagoas, situating the distance between the city of Santana do Ipanema and Capital Maceió, State of Alagoas, Brazil.

\section{The origin of the June celebrations (Festejos juninos)}

The religious celebrations related to the Saint John (or Junino cycle) that begins on the eve of Saint Anthony's Day (June 12) and extends until the 29th of the same month (Saint Peter's Day). Saint John is celebrated on the 23rd and 24th, the eve of the day of the saint. We know that the Jesuit priests brought the Catholic feasts to Brazil in the sixteenth century as Friar FernãoCardim (1584) and that their acceptance was immediate by the aesthetic content of the fires and fires.

\section{Effects of burnings on human health}

Nitrogen dioxide: NO2, a chemical compound consisting of two oxygen atoms and one nitrogen atom; whose chemical formula is NO2. A brown or reddish-brown gas with a strong and irritating odor is very toxic, and a powerful oxidizer which, in reactions in the atmosphere, can give rise to nitric acid (HNO3), as well as organic nitrates which contribute to phenomena with high Environmental impact, such as acid rain and the eutrophication of lakes and rivers. Children and the elderly are the two age groups that have been shown to be most susceptible to the effects of air pollution, and this has been associated with decreased lung function, school absences, decreased peak flow rates in normal children and increased use of medications, in addition, changes in the immune system of normal people. In developing countries, five million children under the age of five die each year from respiratory infections [3].

In Latin America, respiratory diseases kill more than 80,000 children a year, and almost half of these deaths occur in Brazil... Data from the Ministry of Health indicate that 5,945,833 children up to the age of 14 were hospitalized in network hospitals Between 2000 and 2006 due to pulmonary problems, 31.8\% of which were registered in the Southeast region; $9.5 \%$ in Minas Gerais and $0.06 \%$ in the city of Divinópolis, State of Minas Gerais, Brazil [4].

As most diseases have multiple etiological factors, the task of assessing the human health effects of air pollution is not 
easy and there is no scientific basis for qualifying all of its risks. Because of research with particulate matter as a pollutant, and when consultations for asthma attacks are correlated in patients, in emergencies, there is a clear correlation between the number of visits and exposure to particulate matter.

\section{The bonfires in Santana do Ipanema Brazil}

In the city of Santana do Ipanema, as well as in much of the national territory, the Junino period is intensely lived. When June arrives, it is common to find small farmers selling wood in donkey carts, the origin of this wood are the native forests, or what remains of them, around the city. The bodies responsible for restraining this practice do not have sufficient force to supervise and punish those responsible. The choice and the cut are made without the slightest concern with the deforestation of the native forests, there is no concern with reforestation, and since there is no inspection by any environmental protection, organization every year it is noticed that more and more the forests succumb to the Sickle and ax cut. From the houses of rich families, even the houses of the periphery are lit and burned bonfires in allusion to the holy June. Nevertheless, this realization has long been perceived.

\section{Incidences of respiratory diseases in the city of Santana do Ipanema}

It is observed that in the month of June, due to the existence of the June festivities, there is a higher incidence of registered cases of diseases. It is clear that children are the most susceptible to be affected by respiratory diseases, in the three specialties: Influenza (A) Chronic Diseases of the Lower Airways and diseases of the Respiratory System in general. It is evident that the condition of the infantile state, refers to individuals in the age group from 0 (zero) to 09 (nine) years of age, to be more susceptible to respiratory diseases, according to the infectious physician of the Hospital Dr. Clodolfo Rodrigues de Melo, in an interview granted, this occurs due to the child having his immune system still in training.

Acute respiratory infections, especially pneumonia, represent an important part of the cause of death in children in developing countries. It is estimated that about 5 million deaths occur in children less than 5 years of age, $70 \%$ of which are caused by pneumonia [1]. In Brazil, data from 2000 show that $10.2 \%$ of 15,000 deaths in children up to 10 years of age occurred due to respiratory diseases [5]. It is possible to notice that of the group of three diseases that were diagnosed at the José Abdon Malta Marques Diagnostic Center; the cases with the highest incidence of increase were in the area of Pediatrics. What draws attention is that in the months after June, there is an increase in cases detected and attended at the Diagnostic Center. In the months of June, July and August the cases of respiratory diseases show a jump in relation to the other months.

In 2011, 148 cases of Pneumonias or Influenza (A) were registered, of this total, 78 were diagnosed as General Clinic, with a percentage of $52.7 \%$, and in the Pediatric specialty registered 70 cases, which gave a percentage of $47.3 \%$ of the total. With regard to cases of chronic diseases of the lower airways, the incidence of 121 cases was observed, 30 were in the General Clinic which gave a percentage of $24.79 \%$ of the cases and 91 cases were in the pediatrics which gave a percentage of $75.21 \%$ of the total.

Regarding Respiratory Tract Diseases (RTD), 93 cases were recorded, 19 of which were in the General Clinic, representing a percentage of $20.43 \%$, and 74 in Pediatrics, with a percentage of $79.57 \%$. From May to August 2011, of the 66 cases registered as Influenza (A) or Pneumonias, 26 were in the General Clinic, with a percentage of $39.40 \%$, while in the Pediatrics there were 40 cases with a percentage of $60.60 \%$. In the cases of Chronic Diseases of the Lower Airways (CDLA), 85 cases were recorded, of which 14 were in the General Clinic, which gave a percentage of $16.47 \%$, while in the Pediatrics, 71 cases were involved, a percentage of $83.53 \%$. With regard to Respiratory Diseases, 50 cases were recorded. Of these, 14 cases were in the General Clinic, resulting in a percentage of $28 \%$, already in the Pediatrics were 36 cases, resulting a percentage of $72 \%$. In the months of June and August of the analyzed years, from 2008 to 2011, there is an increase in cases of respiratory diseases. It can be seen that there is a higher incidence of cases in the urban area. This is related to population density, higher than in the rural area.

It is evident that the number of cases of respiratory diseases in young people is much lower than in adults and children. With regard to the higher incidence of respiratory diseases in the urban area, the number of fires should be considered, more in the urban than in the rural areas. In the urban zone, there is also greater inhalation of smoke from the fires. It is noticed that women are more susceptible to respiratory diseases in this period. For two years, the average monthly hospitalizations for asthma were 270.8 . The women constituted $56.9 \%$ of the patients and the babies had the highest rates, with 1,639 visits, followed by the group of children between five and ten years. The months with the greatest number of hospitalizations were from October to December (33.06\% of hospitalizations), indicating an increase in hospitalization for asthma in the months of cane straw burning [6]. It is noticed that between October, November and December, in a total of 90 cases of registered respiratory diseases, it was observed that $24.44 \%$ were cases of diseases in children; $2.22 \%$ were cases of diseases in young people and $62.22 \%$ were the percentage of cases registered in adults.

Of the 327 reported cases of respiratory diseases in the period from January to June 2011, it was observed that $18.96 \%$ were of diseases in children; $2.07 \%$ were cases registered in young people and $77.06 \%$ represent the percentage of cases of respiratory diseases recorded in adults. There were 307 cases of respiratory diseases in the Urban and Rural Zones, of which 73 cases occurred in the Rural Zone, which gives a percentage of $23.77 \%$. In the Urban Zone there were 234 cases, 
corresponding to $76.23 \%$. The data correspond to the period from July to November 2011. The cases of respiratory diseases of patients who were admitted to the José Abdon Malta Marques Diagnostic Center from January to December, from 2008 to 2011 Analyzing the numbers, it is found that in 2011, the year of least incidence Of cases registered in that public Health unit. Other factors that are not the subject of the research are related to the climatic aspects and/or to a greater offer of professionals in the respiratory diseases care sector at that center. The reduction of impacts caused by climate variability in the Brazilian population can only be achieved by understanding and modifying the social vulnerability factors that affect these populations in their specific geographic contexts [7]. Concerned with the quality of life of the urban (and, also, environmental) population, geographers are increasingly interested in studies on the climate of cities and their interference in the daily lives of the population.

The impact on health, especially in the aggravation of some pathologies, generated both by the behavior of some climatic elements and by the quality of the air, and the damages to the urban dynamism caused by some extremes of precipitation, will be our vehicle of return to the Idea that, after all, we are not immune to the consequences of our actions on the environment.

Between the years, 2008 to 2011 there is a decline in the number of cases of respiratory diseases. In 2011, there is a decrease in registered cases between the months of May and June; however that number increased in July, (perhaps due to the fires of June and the proliferation of smoke). In other years, there is always an increase in cases.

It is as follows:

o In 2008, there was a 50\% increase in cases between May and July. In the following year (2009), there is a 33.55\% decrease in cases between May and July.

o In 2010, there is an even greater decrease, of $10.16 \%$ in cases between May and July. In the following year (2011), there was an increase of $47.94 \%$ in cases between May and July.

o The associations between air pollutants and hospital admissions in Brisbane, Australia, a city with low concentrations of air pollutants, found that there was a worsening of pre-existing diseases, with exacerbation mainly of respiratory symptoms [8].

o Patients living in urban areas are more susceptible to respiratory diseases than people living in rural areas. This finding will support another factor: the number of inhalations made in patients from the city of Santana does Ipanema, whose highest index is in the urban area. (Data referring to care in rural and urban areas in the months of November and December were not available) [9-12].

o With a total of 1,186 cases, of which 224 are cases of the Rural Zone and correspond to $18.88 \%$ and the 962 cases correspond to $81.11 \%$ of the cases registered in the Urban Zone. The percentage of $62.23 \%$ corresponds to the difference between the attendances registered in the Urban and Rural Zones [12-17].

\section{Final Considerations}

o The cases of children and women with respiratory problems increased in the months following the festivities. The number of respiratory problems is higher in the urban area than in the rural area.

o The sociocultural-religious phenomenon of lighting bonfires, on the occasion of the June celebrations, intensifies the problems of public health, besides the environmental problem coming from this tradition.

o Campaigns to reduce the quantity of lit fires are recurrent, it is suggested that only one per neighborhood, or haystack, should light up during the event.

\section{References}

1. Fabiana dos, Teixeira JW; Camelo V, Alves G (2014) Viabilidade de sementes de espécies nativas do curimataú oriental da Paraiba. LXV CONGRESSO NACIONAL DE BOTÂNICA XXXIV ERBOT Encontro Regional de Botânicos - MG, BA, ES Botânica na América Latina: conhecimento, interação e difusão 18 A 24 De Outubro De 2014-Salvador -Bahia-Brazil.

2. http://acertodecontas.blog.br/atualidades/alunosda-ufpe-fazemprotesto-contra-fogueiras

3. Arruda, Moacir Bueno (2001) Ecosistemas Brasileros. Edição: IBAMA.

4. Ricetto AGL, Zambom M, Pereira I, Morcillo A (2003) Complicações em crianças internadas com pneumonia: fatores socioeconômicos e nutricionais. Revista da Associação Medica Brasileira 49(2): 191-195.

5. Monteiro CAFO (1976) Clima e a organização do espaço no Estado de São Paulo: problemas e perspectivas. São Paulo: IGEOG/USP, (Série "Teses e Monografias").

6. Boopathy R, Asrabadi BR, Ferguson TG (2002) Sugar cane (Saccharum officinarum $L$ ) burning and asthma in Southeast Louisiana, USA. Bull Environ Contam Toxicol 68(2): 173-179.

7. Confalonieri Uec (2003) Variabilidade climática, vulnerabilidade social e saúde no Brasil. In: Terra Livre. São Paulo: AGB 19(20): 193-204.

8. Petroeschevsky A, Simpson RW, Thalib L, Rutherford S (2001) Associations between outdoor air pollution and hospital admissions in Brisbane, Australia. Arch Environ Health 56(1): 37-52.

9. Sonia M, Inês M, Lourdes C, Alfésio Luís F (2004) Poluição atmosférica e doenças respiratórias em crianças na cidade de Curitiba, PR. Revista de Saúde Pública 38(5): 695-700.

10. Cardim, Fernão (1980) Tratados da gente e da terra do Brazil. Belo Horizonte.

11. Chianca, Luciana (2007) Devoção e diversão: Expressões contemporâneas de festas e santos católicos Revista Anthropológicas. ano 11 18(2): 49-74.

12. Chor D, Faerstein Ec (2000) Um enfoque epidemiológico da promoção de saúde: as idéias de Geofrey Rose. Cad Saúde Pública, 16(1): 241244.

13. Duarte DP (1995) Considerações sobre a vegetação da Caatinga. Departamento de Fitotecnia.CCA/UFPB. Areia. 
14. Monteiro CAF (2003) Teoria e clima urbano. In: Clima urbano (Ed.), São Paulo: intexto, pp. 09-68.

15. http://dx.doi.org/10.1590/S1806-37132004000500008.

16. Brasil, Ministerio (2010) Secretaria de Atenção àSaúde.Departamento de Saúde Básica. Doenças respiratórias crônicas. Serie A normas e manuais técnicos.Cadernos de atenção básica. 17.h t t p:/ / w ww.s cielo.br/s cielo.ph p? pid=S 0103 $40142002000100008 \&$ script $=$ sci_arttext
This work is licensed under Creative Commons Attribution 4.0 License

DOI:_10.19080/CTBEB.2017.05.555655
Your next submission with Juniper Publishers will reach you the below assets

- Quality Editorial service

- Swift Peer Review

- Reprints availability

- E-prints Service

- Manuscript Podcast for convenient understanding

- Global attainment for your research

- Manuscript accessibility in different formats

( Pdf, E-pub, Full Text, Audio)

- Unceasing customer service

Track the below URL for one-step submission https://juniperpublishers.com/online-submission.php 